This item was submitted to Loughborough's Research Repository by the author.

Items in Figshare are protected by copyright, with all rights reserved, unless otherwise indicated.

\title{
Coercive redistribution and public agreement: re-evaluating the libertarian challenge of charity
}

PLEASE CITE THE PUBLISHED VERSION

http://dx.doi.org/10.1080/13698230903326281

\section{PUBLISHER}

(c) Taylor \& Francis

\section{VERSION}

AM (Accepted Manuscript)

\section{PUBLISHER STATEMENT}

This work is made available according to the conditions of the Creative Commons Attribution-NonCommercialNoDerivatives 4.0 International (CC BY-NC-ND 4.0) licence. Full details of this licence are available at: https://creativecommons.org/licenses/by-nc-nd/4.0/

\section{LICENCE}

CC BY-NC-ND 4.0

\section{REPOSITORY RECORD}

Chambers, Clare, and Phil Parvin. 2019. "Coercive Redistribution and Public Agreement: Re-evaluating the Libertarian Challenge of Charity”. figshare. https://hdl.handle.net/2134/15492. 


\title{
Coercive redistribution and public agreement: re-evaluating the libertarian challenge of charity
}

\author{
Clare Chambers $^{\mathrm{a}^{*}} \&$ Phil Parvin ${ }^{\mathrm{b}}$ \\ ${ }^{a}$ Jesus College, University of Cambridge, ${ }^{b}$ Trinity Hall, University of Cambridge
}

\begin{abstract}
In this article, we evaluate the capacity of liberal egalitarianism to rebut what we call the libertarian challenge of charity. This challenge states that coercive redistributive taxation is neither needed nor justified, since those who endorse redistribution can give charitably, and those who do not endorse redistribution cannot justifiably be coerced. We argue that contemporary developments in liberal political thought render liberalism more vulnerable to this libertarian challenge. Many liberals have, in recent years, sought to recast liberalism such that it is more hospitable to cultural, religious, and ethnic diversity. This move has resulted in increased support for the claim that liberalism should be understood as a political rather than comprehensive doctrine, and that liberal institutions should draw their legitimacy from agreements made among members of an appropriately conceived deliberative community, rather than from controversial liberal principles like individual autonomy. We argue that, while this move may indeed make liberalism more compatible with cultural diversity, it also makes it more vulnerable to the libertarian challenge of charity. Not all versions of liberalism are troubled by the challenge, but those that are troubled by it are increasingly dominant. We also discuss G. A. Cohen's claim that liberal equality requires an 'egalitarian ethos' and argue that, if Cohen is right, it is difficult to see how there can be an adequate response to the libertarian challenge of charity. In general, our argument can be summarised as follows: the more that liberalism is concerned accurately to model the actual democratic wishes and motivations of the people it governs, the less it is able to justify coercively imposing redistributive principles of justice.
\end{abstract}

Keywords: taxation, coercion, liberalism, deliberative democracy, incentives, G. A. Cohen

Egalitarian arguments in favour of redistribution have attracted criticism from libertarians. ${ }^{1}$

Robert Nozick's Anarchy, State and Utopia set the scene for debates about the legitimacy of taxation, social justice, and self-ownership which dominated Anglo-American political philosophy throughout the 1970s and early 1980s. More recently, however, the debate has shifted. Debates about redistribution now tend to centre on the luck egalitarian approach, with

\footnotetext{
*Corresponding author. Email: cec66@cam.ac.uk
} 
its issues of choice and responsibility, rather than on justifying the redistributive state. Meanwhile, many liberal thinkers have chosen to focus on a very different set of issues, primarily those of identity, community, citizenship, and culture.

Communitarian critics of liberalism focused on fundamental questions about the conception of the individual that lay at the heart of the Rawlsian model. These critiques yielded insights into the nature of the self which forced many liberals to re-think their commitments to principles such as individuality and autonomy. Many liberals felt the need to demonstrate how liberal principles could be compatible with individuals' rootedness in cultural, religious, and other communities which shape their preferences and conceptions of the good (Sandel 1982; MacIntyre 1996; Walzer 1985; Taylor 1992). While liberals such as Joseph Raz and Will Kymlicka (who we might describe as adopting a 'comprehensive' understanding of liberalism) controversially sought to ground individuals' capacity for autonomy precisely in these memberships (Raz 1986; Kymlicka 1989), many other liberals sought to empty liberalism of its substantive commitments on the grounds that liberalism should be as neutral or impartial as possible between rival understandings of such fundamental matters as identity and autonomy.

This trend became even more pervasive in the wake of debates about multiculturalism and minority rights (which largely grew out of earlier debates between liberals and communitarians). For many, it would seem, the most pressing issue facing liberal political theory is not whether and how social and political institutions should distribute benefits and burdens, but how liberalism might be re-interpreted in order that it accommodate cultural, ethnic, and religious diversity.

This political or impartialist approach to understanding and justifying liberal justice is now the dominant form of liberalism. The claim that liberalism should not seek to ground its conception of justice in controversial liberal conceptions of the good but in the common 
agreement of all those diverse individuals who are to be bound by them has been advanced by a growing body of thinkers including John Rawls, Charles Larmore, William Galston, and many others. All claim that liberalism should - as far as possible - shun the justification of liberal justice in substantive, controversial principles in favour of agreements derived from appropriately configured public deliberation in the interests of deriving a conception of justice which takes seriously the claims of cultural and religious minorities.

It is our contention that, even if these reinterpretations of liberalism render liberalism more hospitable to communitarian or multiculturalist concerns, they leave it more vulnerable to libertarianism. We focus on one libertarian claim in particular: that coercive redistribution is neither required nor justified. One of Nozick's arguments against state redistribution is that the duty we have to help the poor is a moral duty to perform acts of charity, not a political obligation to comply with state redistribution. We call this claim the libertarian challenge of charity: why should principles of redistributive justice be coercive? ${ }^{2}$

We argue that, while some forms of liberal egalitarianism can answer the libertarian challenge of charity fairly straightforwardly, others cannot. In general, we argue that liberals who care about establishing a regime of coercive principles which underwrite redistributive initiatives aimed at alleviating poverty should think twice about adopting the political liberal model, for it may be that in doing so they undermine their ability to rebut the libertarian challenge of charity. We begin in section 1 by outlining three kinds of responses that liberal egalitarians might provide to the libertarian challenge (in favour of principles being coercive): responses of disagreement about the principles of justice, of unreasonableness on the part of some individual members of the polity to engage with others on fair terms, and problems of motivation to act justly. We then discuss, in the following sections, which kinds of liberalism contain the normative resources to appeal to these responses. We assume throughout that the normatively weakest response to the libertarian challenge is that of problems of motivation, 
and that all liberals are able to appeal to this response. However, in the final part of the chapter we explore in depth the arguments put forward by one particular egalitarian thinker G.A. Cohen - who believes that this response is not open to liberal egalitarians. We discuss Cohen's argument at length because, if true, his conclusion would have profound implications for liberalism, and if our wider argument holds, for political liberalism in particular. We also argue that Cohen's arguments have a surprising implication: despite his explicit antilibertarianism, his defence of an egalitarian ethos leaves him unable to refute the libertarian challenge of charity.

We therefore make two main claims. Firstly, we argue that recent developments in liberal theory have led to the weakening of liberals' response to the libertarian challenge of charity, and that this is a problem. Secondly, and relatedly, we argue that Cohen's argument for egalitarianism is potentially very damaging to a Rawlsian justification of redistribution and, in particular, to political liberalism, but that - under close inspection - Cohen's claims leave his own form of egalitarianism entirely open to the libertarian challenge. In general, our argument can be summarised as follows: the more that liberalism is concerned accurately to model the actual democratic wishes and motivations of the people it governs, the less it is able to justify coercively imposing redistributive principles of justice.

\section{Reasons for coercion}

Libertarians do not challenge state coercion tout court. Coercion is required to maintain the minimal state, which secures law and order, enforces contracts and defends society from external aggressors. Libertarians are wary of state coercion when it is used to enforce particular moral codes or when, as we focus on here, it is used to compel people to donate some of their resources to assist others. For Nozick, this compulsion is analogous to forced 
labour, violating individuals' rights of ownership over themselves and the fruits of their labour.

An important part of the egalitarian response to libertarianism has been to rebut this libertarian critique of compulsory redistribution. In order to do so effectively, we suggest, liberals need to show not only that redistribution of resources is required in order to secure equality. They must also show why it is legitimate to use coercion to bring about that goal. Egalitarian liberals value liberty as well as equality and often, as in the case of Rawls, prioritise liberty. It is therefore necessary for liberals to explain why liberty can justly be constrained using the heavy hand of the state. If equality can be achieved by other, less coercive means, liberals ought to prefer those to the use of law.

We can identify three general liberal justifications for coercion, which function as responses to the libertarian challenge of charity: disagreement, unreasonableness and problems of motivation. These responses can be offered individually or in various combinations, and stand as placeholders for specific arguments made by particular philosophers.

The first reason why redistributive justice might require coercion is if it is controversial and thus subject to disagreement. If members of a society do not agree on what the principles of justice are, such that a proportion of them deny that the prevailing understanding of 'justice' is in fact just, it will be necessary to enforce those principles coercively. This response, we suggest, is the most robust against the libertarian challenge. In section 2 we discuss this response further and argue that, within liberalism, it is available unproblematically only to comprehensive liberals, for only comprehensive liberals are untroubled by substantive disagreement about justice.

The possibility of disagreement about the principles of justice prompts the Rawlsian distinction between reasonable and unreasonable disagreement. Even if all reasonable people 
agree on the principles of justice, any society may contain unreasonable people who do not wish to co-operate with others on fair terms. The second reason why coercion might be required, then, is that some people are unreasonable. This response is available to most forms of liberalism. However, it may not be easy to distinguish the unreasonable members of society from those who disagree about what justice is. In Rawls' work, unreasonableness is defined as an unwillingness to co-operate fairly with others under conditions of diversity, and is thus intended to stand apart from any comprehensive conception of the good. However, an understanding of reasonableness as willingness to co-operate fairly is an understanding that relies on a particular (liberal) account of justice. If this is true, then an unreasonable person could also be someone who disagrees about the principles of justice. As we point out in section 3, this conclusion is rather problematic for political liberals and those who support deliberative democracy, and makes unreasonableness a rather precarious response to the libertarian challenge.

Even if all people within a society agree on the principles of justice, however, there still may be a role for coercion on the grounds of problems of motivation. A society may have unanimity on the principles of justice, and no unreasonable people. Thus everyone might agree that justice requires a certain level of redistribution. Without coercion, however, people may fail to give the amount of money that justice requires as a result of selfishness or weakness of will. Coercion might thus be required merely to enforce the duties that people agree they have. This response appears to be available to liberals; however, in section 4 we discuss Cohen's claim that Rawlsian liberal justice requires that people are motivated to obey the difference principle in their everyday lives, not only when compelled to do so by law. If Cohen is right, we argue, there can be little or no response to the libertarian challenge.

Finally, note that it is not a response to the libertarian challenge to point to the need for a central institution to co-ordinate redistribution. One role the state plays is to calculate how 
much money is required for redistribution overall, and to inform people how much each is required to pay to meet that end. Without the state (or some other institution) to perform this role the demands of justice could never be met, for even the most perfectly motivated individual would be unable to work out what justice demands she give or who the recipient of her donation should be. Some co-ordinating institution is required, then, but there is no need for it to be coercive. In a society containing perfectly motivated citizens who agree on the principles of justice, all that would be required from the co-ordinating institution would be calculations of each person's just contribution and a fair distribution mechanism. Citizens would be informed of their personal contribution amount, and would then be legally free to donate or not donate it as they pleased. Of course, in the circumstances described, everyone would donate exactly as justice required.

With this typology of responses to the libertarian challenge of charity in place, we now consider which responses are available to which forms of liberal egalitarianism.

\section{The response of disagreement}

The response of disagreement - the claim that redistributive justice can be coercively enforced because not all citizens will agree with its demands - is most easily available to comprehensive liberals. Comprehensive liberals believe that liberalism embodies a commitment to certain substantive ethical principles (such as individual autonomy or equality) and that it is the role of the state to encourage or enforce these values. For these thinkers, liberalism represents an ethical system rooted in the supremacy of certain principles which are taken to express something important and evaluative about the particular ends and ideals that individual persons pursue, and the ends to which the state should be directed.

Galston calls this 'Enlightenment' liberalism as it embodies a general commitment to principles like individual autonomy and equality that we find in Enlightenment thinkers like 
Constant and Condorcet (Galston 2002). Contemporary advocates of this form of liberalism include Raz, Steven Wall, Kymlicka, and the early Rawls, who in general invoke the principle of personal autonomy to underwrite a powerful defence of egalitarianism, equality, and redistribution (Raz 1986; Wall 1998; Kymlicka 1989; Rawls 1971).

Given all this, the comprehensive liberal response to the libertarian challenge of charity is straightforward. Liberalism does not exist merely to operationalise the preferences of all individuals. Instead it must promote only those goals and preferences which are congruent with the ethical principles on which liberalism rests. Comprehensive liberalism is rooted in a commitment to individual autonomy which in turn rests on a commitment to all persons possessing those resources necessary to reflect upon, and pursue, those ends which give their lives value. This right of individual autonomy is one shared by all persons equally, and so it is the responsibility of a liberal state to ensure that all persons equally possess the substantive capacity for autonomy (by ensuring that everyone has access to all those resources necessary for autonomous reflection and free choice). This right trumps any interest that any individual may have in withholding their resources: the redistribution of resources from those who have them to those who do not arises directly from an appeal to the basic principles of equality and individual autonomy which comprehensive liberals take to be at the heart of liberalism. Hence, people may not accept that justice requires them to give up their claim on certain resources in order that they be redistributed to others, but for comprehensive liberals they are simply mistaken: justice does require this, and so these people can be legitimately coerced into contributing to redistributive initiatives.

Political liberals reject this comprehensive approach, citing its foundational principles as too controversial to sustain liberal justice in a world characterised by pluralism. Political liberalism thus eschews as far as possible the comprehensive liberal strategy of grounding its normative prescriptions in particular substantive claims, and seeks instead to establish a freestanding, procedural account of justice capable of providing an ethical framework within which those conflicts arising out of moral and political diversity can be appropriately resolved. As Brian Barry states, liberal principles of justice are not 'designed to tell us how to 
live ... [but] rather how to live together, given that we have different ideas about how to live'. (Barry 1995, p. 77) Or as Charles Taylor puts it, they focus on 'what it is right to do rather than what it is good to be, on defining the content of obligation rather than the nature of the good life'. (Taylor 1992, p. 3) If we are to find truly effective and reasonable grounds for arbitrating between different ends without violating the deeply held self-understandings and beliefs of those involved, political liberals argue, then we must reject comprehensive accounts of the good (and of the self) and establish instead a political conception of justice which stands independent of, and prior to, our more substantive ideas about ourselves and the world. We must, in Charles Larmore's words, define 'the common good of political association by means of a minimal moral conception'. (Larmore 1995, p. 123)

We therefore find in political liberalism a shift in the way liberal principles and institutions are justified. No longer are we to appeal to particular 'comprehensive doctrines'. Rather, we are to appeal to agreements made by citizens in some appropriately modelled account of public reasoning. In doing so, we acknowledge the partial and controversial nature of liberal principles like individual autonomy, and respect the different understandings and perspectives of all those in society who are to be bound by the principles of justice. This shift in the method of justification appears to bar political liberals from providing the first response in our typology. Coercion can no longer be justified on the grounds that some people will disagree with the principles of justice, because such disagreement would invalidate those very principles. That is, the validity of particular principles cannot be established independently of what people think of them, because for political liberals the validity of principles of justice is precisely determined by the common agreement of all those who are to be bound by them.

This response on its own leaves political liberalism particularly vulnerable to the libertarian challenge of charity. ${ }^{3}$ After all, if we can no longer ground liberal justice on an appeal to the overarching supremacy of certain substantive values but must ground it instead 
on widespread common agreements made by diverse individuals or groups through a process of public reasoning, then libertarians are surely justified in suggesting that the need for coercion is weakened. If liberal justice is based on principles which gain their legitimacy precisely from public agreement then it need not be coercive, since justice will be rooted in the expressed preferences and commitments of those involved. Coercion becomes unnecessary.

Of course, most political liberals understand the process of public reason as a hypothetical or ideal one, not one which actually occurs between situated individuals. The more that agreement on liberal principles is understood to be hypothetical, the greater the role for coercion in enforcing those principles. For liberals who ground their redistributive principles in ideal agreements can still argue that actual preferences in the non-ideal real world may not map on to those ideal agreements. Thus the response of disagreement remains available if redistributive principles require only hypothetical agreement.

However, for some theorists the process of agreement must be more concrete. There is a third group of broadly liberal thinkers who extend the arguments put forward by political liberals about the importance of agreement and public deliberation into a much wider normative approach to justifying coercive principles. Consider, for example, Amy Gutmann and Dennis Thompson. 'The process of mutual reason-giving', they say, 'is not equivalent to the hypothetical justifications proposed by some social contract theories. Such justifications may constitute part of the moral reasoning to which some citizens appeal, but the reasoning must survive the test of actual deliberation if it is to ground laws which actually bind all citizens'. (Gutmann and Thompson 2002, p. 157) Importantly, this deliberation 'should take place not only in the private homes of citizens or the studies of philosophers, but in public political forums'.(2002, p. 157) This approach clearly builds on the so-called deliberative turn in liberal theory, which saw thinkers such as Rawls and Larmore replace hypothetical 
contracts with a more fluid, inclusive form of public reasoning about justice that they felt was more capable of incorporating the different conceptions of the good of diverse populations of liberal democratic states. However, it descends from the realm of the hypothetical and describes the actual conditions under which principles of justice are decided and 'fair terms of political cooperation' are set $(2002$, p. 153). In this sense, it represents perhaps the most explicit attempt to ground the justification of principles of justice in agreements among individuals rather than wider controversial principles.

Deliberative democrats vary in the extent to which they ground justice in actual agreement. Some, such as Gutmann and Thompson, do introduce regulative principles into the deliberative process in order that the outcomes satisfy requirements of fairness and equality. However, it is important to note that even these substantive principles are considered morally and politically provisional in the sense that 'both procedural and substantive principles are systematically open to revision in an ongoing process of moral and political deliberation'.(p. 154) Substantive deliberative democrats like Gutmann and Thompson therefore recognise the importance of modelling public deliberation according to certain principles, but regard these principles as provisional in the sense that they might themselves be rejected by those involved. Other deliberative democrats, such as Iris Marion Young, emphasise even more firmly the role of actual agreement in grounding principles of justice. For Young, democratic debate must be circumscribed only by basic procedural fairness, with justice itself emerging from debate rather than being set in advance (Young 2000). ${ }^{4}$

The sort of approach favoured by deliberative democrats is particularly vulnerable to the libertarian challenge of charity since, like political liberals, it is unable to use the response of disagreement. If principles of justice gain their legitimacy from the fact that they are justifiable to all those within a polity who are to be bound by them, it is not possible to argue that coercion is required because some people are unconvinced. If controversial principles are 
not accepted by some members of society this is a problem not of enforcement but rather of legitimacy. In other words, if redistributive justice requires coercion then its normative foundations are undermined.

\section{The response of unreasonableness}

Nonetheless, both deliberative democrats and political liberals are able to provide alternative responses to the challenge of charity. Political liberals, for example, can provide the response of unreasonableness. This response is rooted in the possibility that certain members of the polity might be unreasonable in the sense that they do not wish to cooperate with others on fair terms. While all reasonable people might agree to the principles of justice (arrived at through an appropriately modelled and constrained process of common deliberation), the polity might still contain a proportion of 'unreasonable' people who do not wish to co-operate or engage in the kind of public reasoning demanded by political liberalism. In this sense, political liberals invoke an important distinction between false or mistaken forms of reasoning and unreasonable forms of reasoning. Comprehensive liberals are able to claim that those who disagree with the principles of justice are merely wrong in the sense that they have a misguided notion of what justice requires. Political liberals, on the other hand, avoid such claims (because of their controversial nature) and appeal instead to the notion of reasonableness, defined as this willingness to cooperate on fair terms and derive principles of justice in the appropriate way. In doing so, political liberals seek to avoid having to impose controversial ethical principles or conceptions of the good from the top down. Instead, they seek to establish a process of public reasoning and deliberation which constructs principles of justice from the bottom up (from the reasonable agreements of those bound by them).

The problem, however, is that it is not clear how effectively the political liberal definition of 'reasonableness' avoids the presupposition of substantive, controversial liberal 
values. That is, it is not clear how successful the distinction between 'unreasonable' forms of reasoning and 'mistaken' forms of reasoning is, when we realise that reasonableness is defined by appeal to controversial liberal principles. This is an important issue, and there exists a significant body of work exploring the extent to which political liberalism succeeds in distancing itself from controversial, comprehensive principles like autonomy. ${ }^{5}$ It is not possible to go into detail here, then. However, it is important to note that political liberalism (in particular the varieties argued for by Larmore and the later Rawls), like the impartialist liberalism of Barry, is no more a mechanism for merely operationalising the desires and preferences of citizens than comprehensive liberalism. The kind of public reasoning about justice presented by political liberals like Rawls and Larmore would appear to be structured and constrained in such a way as to produce agreements which are in line with traditional liberal principles of equality and autonomy. Indeed, Rawls accepts that his form of political liberalism is applicable to only liberal societies, and thus accepts the contingency of its fundamental premises of political freedom and equality (Rawls 1993). It seems, then, that while political liberals might seek to reinterpret the grounds of liberal justification away from overarching, controversial accounts of value, they succeed only in moving it into a process of agreement and public reasoning which itself embodies precisely those same controversial principles. In defining what kinds of reasons and arguments participants in public dialogues about justice might and might not legitimately engage in, and in requiring that all individuals should have access to these deliberations on a basis of equality, political liberalism can be seen to embody substantive commitments to controversial values in the same way as comprehensive liberalism. Political liberalism cannot avoid invoking the value of political equality and individual autonomy because it is important to political liberals that the process of public reasoning about justice is conducted in a particular way, subject to particular constraints, between people understood to be free and equal. 
Consequently, the political liberal response to the libertarian critique is actually similar to the comprehensive liberal response. Because political liberals require that we understand the process of public reasoning to be constrained by basic liberal principles of freedom and equality, their account of public reasoning effectively represents a mechanism for filtering out non-liberal arguments and, hence, non-liberal outcomes. In the sense that political liberalism seeks to justify liberal justice in public agreements, and then defines the process by which these agreements are legitimately made as circumscribed by comprehensive liberal principles, political liberalism ultimately grounds the justification of liberal justice in those same substantive liberal values as comprehensive liberalism.

Political liberals may not accept this, of course, for in doing so they jeopardise their wider aim of establishing liberal justice independently of controversial principles. Political liberals are therefore faced with a choice. They could accept that their justification for liberal justice rests on appeals to controversial principles, in which case they are able to respond as robustly to libertarians as comprehensive liberals by appealing to those principles (at the expense of their wider aim of establishing political justice independently of such principles). Alternatively, they could cling to their original aim of establishing liberal justice independently of controversial principles and accept that in doing so their response to the libertarian challenge of charity is weakened. In response to the latter option libertarians might reasonably suggest that if political liberals drop their more controversial claims about the way in which people should engage in public reasoning, and ground principles of justice in agreements about what people actually do want, then the argument for coercion is weakened. Libertarians would be right about this, as in this event, political liberals would be forced to appeal only to the third (much weaker) response of motivation. 


\section{The response of motivation}

We have assumed that the thinkers discussed so far are able to make use of the third response to the libertarian challenge of charity: the response of motivation. In other words, the various forms of liberal egalitarianism so far considered can argue as follows: 'The principles of distributive justice under consideration may well be those that everyone agrees with, or cannot reasonably reject, or accepts actually to be just. Nonetheless, it is still necessary to enforce those principles coercively, since people may lack the motivation to do that which they accept they ought. In short, state coercion is needed to overcome weakness of will'.

Indeed, we have suggested that political liberals and deliberative democrats need the response of motivation, if they are to succeed in grounding justice independently of any appeal to controversial conceptions of the good. Their alternative response of unreasonableness risks collapsing into the response of disagreement, and this latter response is available to only comprehensive liberals. However, G.A. Cohen's recent work suggests that egalitarian liberals cannot make use of the response of motivation since what he terms an 'egalitarian ethos' is crucial to egalitarianism.

This claim is of critical importance. If Cohen is right that justice requires an egalitarian ethos, it must also be the case that the libertarian challenge of charity is correct and that coercive enforcement of redistribution is at least unnecessary and at most unjust. It also suggests that those political liberals who do not wish to give up their wider project of establishing liberal justice independently of controversial liberal principles are not - in the absence of the response of motivation - able to rebut the libertarian challenge of charity. It is therefore important to discuss Cohen's claims in detail in order to determine, firstly, how damaging they are to political liberalism and, secondly, how susceptible these arguments themselves are to the libertarian challenge. 
In a number of recent works Cohen considers what sorts of inequalities are permitted by Rawls' difference principle. The difference principle allows inequalities only if they are necessary to benefit the worst off, and is based on the thought that it is better to have more primary goods than fewer, even if one can have more only at the expense of increased inequality. The question then becomes when and why an inequality would benefit the worst off, and thus be justifiable.

An inequality in primary goods might benefit the worst off in two main ways. First, it might be necessary to pay people more in order for them to perform work that is extremely socially beneficial. If no one were to do this sort of work everyone, including the worst off, would suffer. So, for example, the difference principle might justify paying people more to become doctors if, without the increased salary, there would be insufficient doctors to meet everyone's healthcare needs. It is usually thought this situation will occur in highly skilled jobs, where employment vacancies can be filled by only a few people. Note, however, that there is no necessary connection between this sort of income inequality and skilled work. It is possible that some unskilled jobs could be so unpleasant that no-one were willing to perform them without extra wages (refuse collection or abattoir work, for example). In actual societies the threat of unemployment and poverty suffices to induce some people to take such jobs without extra income. In a Rawlsian society, however, the baseline of equality means there are fewer desperate people, and thus it is more likely that unpleasant but socially necessary unskilled jobs would warrant higher salaries.

The second main way in which an inequality might benefit the worst off is through some version of the trickle-down effect. On one version of the trickle-down effect it does not matter what work the person with the higher income is doing, or even if they are doing any work at all. Since wealthy people spend more money and pay higher taxes, their increased consumerism contributes to employment and welfare for those who are less wealthy. On 
another version of the trickle-down effect, the worst-off are benefited by the work the wealthy are doing. This applies if increased income for some encourages entrepreneurial activity which directly creates employment opportunities for the worst off. Thus a person might be tempted to start up a new business, creating jobs for others, if she is thereby able to enjoy increased income from the business's profits. If such increased income were not available she might choose alternative work that does not create jobs.

Note one important difference in these justifications of inequalities. In some cases the unskilled socially-necessary jobs and the increased consumerism trickle-down effect - it does not matter who is given the extra money. In the case of the unskilled jobs, any ablebodied person who is willing to perform them is able to perform them, and thus the extra income is available to anyone. In the case of increased consumerism, it is not necessary that the extra income be allocated in relation to work at all. Allocating it to random lottery winners would have the same effect. However, in the remaining two cases - the skilled sociallynecessary jobs and the entrepreneurial trickle-down effect - the extra income is available only to those people who have the necessary skills to perform the skilled labour or generate the extra jobs. These considerations might make a Rawlsian individual in the original position happier about the first sorts of inequalities than the second. For the first sorts of inequalities are, in principle, available to everyone, whereas the second sorts of inequalities are confined to those who are lucky that their particular skills are socially valuable.

Cohen does not make this distinction or separate these four sorts of inequalities. He does, however, highlight another ambiguity in the difference principle. The principle states that inequalities are just only when they are 'necessary' to benefit the worst-off, but it does not explain what it means for an inequality to be necessary. On what Cohen calls the 'strict' reading of the difference principle, extra income is justified only if the work in question cannot be performed without extra income, perhaps because it is particularly burdensome. If 
it were to be paid at the same rate as other work, the extra burdens would leave the worker in a disadvantaged position compared to others. Unpleasant or particularly difficult jobs fall into this category. Cohen does not criticise this strict form of the difference principle (Cohen 1991, p. 296).

On the 'lax' reading of the difference principle, on the other hand, an inequality is justified simply if it is needed to persuade or induce someone to perform work that benefits the worst off (or to perform more work so as to increase productivity and benefit them that way). Cohen terms this the incentives argument, and writes that he will 'mainly be interested in the case where a talented rich person puts it forward' (1991, p. 278) Cohen's claim is that when talented rich people put forward the incentive argument they resemble kidnappers who are able to hold others to ransom (1991, p. 278). Since only some people are able to perform the skilled socially-necessary jobs, these talented individuals are able to demand more than is necessary to compensate them for any extra burden. This is not the case with the unskilled socially-necessary jobs: since everyone could in principle perform them, there is no scope for some to demand more income than offsets the extra burdens (market forces should result in an equilibrium between income and burden).

Cohen's argument runs as follows. If citizens agree that Rawls' principles of justice are indeed just, then they affirm the principle that inequalities should be permitted only if they benefit the worst off. However, if a talented person demands more money for performing a socially-necessary skilled job (more than others are getting, and more than is needed to offset the burdens of that job) then she is acting in a way that contradicts the difference principle. By demanding an extra incentive, she is demanding a payment that is not strictly necessary in order to benefit the worst-off. It is entirely within her control to perform the work without demanding the inequality. It would therefore be possible for her to act in 
such a way as to benefit the worst-off without thereby creating an inequality and, if she really is committed to the difference principle, this is what she would do. As Cohen puts it:

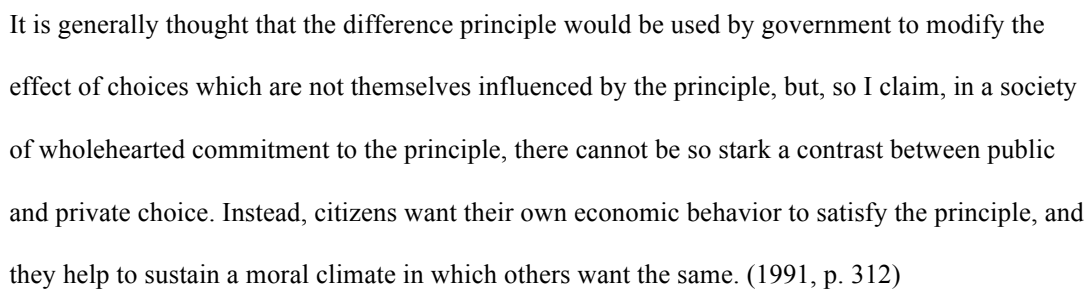

Should we assume that a society will nurture 'wholehearted commitment to the principle'? For Cohen, it is true of both Rawls' writings and of egalitarian theories of justice in general that society must contain such commitment. It is true of Rawls since he states that his theory is intended to apply to a well-ordered society, one in which citizens know what the principles of justice are, agree that they are indeed just, and are motivated to comply with them (1991, p. 318). In If You're An Egalitarian, How Come You're So Rich?, Cohen argues that it is also true of egalitarian theories in general:

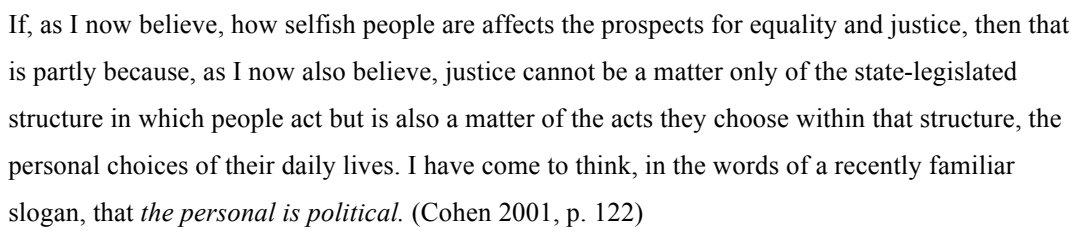

If Cohen is correct, then egalitarians cannot make the response of motivation against the libertarian challenge, for they cannot claim that citizens who accept the principles of justice will lack the necessary motivation to implement them. However, we also want to show that Cohen's arguments go further. If an egalitarian ethos is a requirement of justice, it follows that coercive enforcement of redistribution is unjustified. We make this argument in three stages. First we discuss how the ethos might be a necessary condition for justice. 
Second we argue that, if it is necessary for justice, then the ethos must be sufficient. Finally we argue that, if the ethos is sufficient, then coercion is both unnecessary and unjustified.

\section{Is the ethos necessary?}

We have seen that Cohen is committed to the idea that the ethos is necessary for justice.

However, the scope of this claim is unclear. Presumably all egalitarian theorists can agree that an egalitarian ethos is necessary if society is to be ideal or utopian. To put this thought another way: an ideally-just society will need coercion for neither redistributive nor criminal justice, since no-one will be motivated to shirk their obligations or violate the rights of others. Any egalitarian can agree that such a situation is desirable and that any society that lacks such an ethos is pro tanto non-ideal. Thus, if the claim 'the egalitarian ethos is necessary for justice' means 'the egalitarian ethos is necessary for a utopian, ideal society', all egalitarians can agree. But such a claim is not very significant since we are unlikely ever to reach utopian, fully-ideal conditions and since Rawlsians are unlikely to find it problematic that Rawls offers no considerations as to how to achieve such conditions.

Cohen's arguments lack force, then, if they simply point out that a society cannot reach utopia without an egalitarian ethos. The question then is whether utopia is the same as justice; in other words, whether it is possible for a society to be just and yet non-utopian. To put this issue in a different way: Cohen's arguments are most significant if they indicate that justice of any sort is impossible without an ethos or that, without an ethos, a society is seriously deficient. Cohen does seem to hold this position: he writes that 'a just society is normally impossible without [an egalitarian ethos]' (Cohen 1991, p. 316). This claim might be justified in one of two ways. It might be based on the idea that justice is an all-or-nothing concept, such that a society is either fully, ideally just or else hopelessly unjust, with no normative distinction between levels of injustice. This position is implausible: it is perfectly 
possible to say that some societies are more just (or less unjust) than others, according to such considerations as the proportion of positions of advantage that are filled according to the equal opportunity principle and rewarded according to the difference principle. On the other hand, then, the claim of necessity might be based on the idea that justice is a matter of degree but that, without an egalitarian ethos, the 'level' of justice that a society can obtain is significantly deficient.

Samuel Scheffler rejects the idea that a society cannot reach (an acceptable level of) justice without an egalitarian ethos. Scheffler argues that Cohen fails to demonstrate that Rawls' theory requires an egalitarian ethos since it is compatible with Rawlsian justice that the state simply forbid any increased salaries that are incentives rather than compensation for special burdens. As Scheffler puts it, 'an ethos of justice would not actually be necessary to produce an economic distribution satisfying the strict [difference] principle - such a distribution could be achieved by the coercive structure alone' (Scheffler 2006, p. 118). ${ }^{6}$ If Scheffler is right then the distinctiveness of Cohen's position is lost. In order to rebut Scheffler and maintain his own position Cohen must assert that the ethos is necessary: the coercive state cannot bring about equality without it (and thus the state is not a sufficient condition).

Support for this position is found in the following passage from Cohen:

We are left with the strict difference principle, which government cannot by itself implement. For the strict difference principle to prevail, there needs to be an ethos informed by the principle in society at large. Therefore, a society (as opposed to its government) does not qualify as committed to the difference principle unless it is indeed informed by a certain ethos, or culture of justice. Ethoses are, of course, beyond the immediate control of legislation, but I believe that a just society is normally impossible without one, and Rawls himself requires that there be a nurturance and cultivation of appropriate attitude in the just society that he describes. (Cohen 1991, pp. 315-6) 
Cohen is committed to the view that the ethos is necessary for justice, then. However, this claim does not yet concede the libertarian challenge. For that, we need to show that the egalitarian ethos is sufficient for justice.

\section{Is the ethos sufficient?}

The ideal that the ethos is necessary suggests that it is also sufficient. For Cohen's very idea of an egalitarian ethos is that it is a property of individual citizens which leads them to be motivated to forego personal gain in order to bring about distributive justice. If people are willing to forego personal gain in the incentives case (in other words, if they are willing to do socially-necessary work without demanding extra pay so as to benefit the worst-off), then there seems no reason why they would not also willingly donate their 'tax' burden without it being coercively demanded by the state. We noted at the start of this chapter that it would be possible for the state to take on a non-coercive co-ordinating role, calculating everyone's fair burden but not demanding that they pay it. If citizens have an egalitarian ethos of the sort Cohen thinks they need, there is no reason why they would not pay their fair share freely and happily. There is no need, in other words, to enforce coercive taxation laws since citizens will contribute willingly without.

Thomas Nagel offers an argument against this idea that something like an egalitarian ethos is sufficient for justice. In a piece aimed explicitly at rejecting the libertarian challenge of charity Nagel argues that 'a person who is willing and, indeed, eager to contribute through taxation might be unwilling to give off her own bat'. (Cohen 2001, p. 169) Nagel's thought is that one might agree on the principles of justice but lack motivation, and thus coercive taxation is justified. Cohen devotes several pages to arguing against Nagel's position, since he rightly identifies Nagel's claim as undermining the need for an egalitarian ethos. Cohen's argument rests on a distinction between difficulty and cost. Firstly, donating voluntarily and 
donating via taxes are equal in cost. That is to say, if one does the calculations correctly (or if they are done by a central co-ordinating institution), the amount due will be the same under both systems. The only reason to prefer coercion over donation, then, is that the two systems are not equal in their difficulty: it is more difficult to spur oneself to voluntary action since one faces constant temptation to defect in the name of self-interest. However, Cohen argues, one can 'avoid such recurrent difficult voluntary decisions' (Cohen 2001, p. 171) by setting up a standing order with one's bank. Thus, Cohen concludes, 'we have not been supplied with a reason for not giving off our own bat what we would be willing for the state to take'. (2001, p. 172)

Having thus refuted Nagel, Cohen does not consider the original context of Nagel's argument: an attempt to rebut Nozick's libertarian challenge. Cohen thus appears not to notice that his refutation of Nagel is also a defence of this aspect of libertarianism. For if there is no need to supplement the egalitarian ethos with coercion in order to overcome difficulties in contributing, what could be the role of coercion?

One possible role for coercion even if an egalitarian ethos prevails is as a solution to assurance problems. An individual might be motivated to comply with the principles of justice only if all other members of her society are also complying, and it might be only coercion that assures her of this universal (or near-universal) compliance. But this suggestion raises a number of questions. The first is whether it is reasonable for an individual with an egalitarian ethos to insist on being assured of near-universal compliance. The second is whether coercion would in fact be necessary to provide this assurance.

It is clear that assurance is problematic in societies that are not characterised by an egalitarian ethos, but this is not the matter under consideration here. If assurance is indeed to be a reason why the ethos is not sufficient, then assurance problems must remain even when the ethos is universally shared. And it seems possible for assurance problems to remain even 
under conditions of a universal ethos only if members of a society lack information about the extent to which the ethos is in fact shared. In a society where citizens had perfect information about others' propensity to egalitarianism, individuals would have no grounds on which to withhold their contributions for lack of assurance. And, while state coercion is one possible means of solving assurance problems, it is not the only such means. Cohen notes that 'The beauty of a state-imposed duty, or of a general ethos of giving' (2001, p. 175. Emphasis added) is that either one can solve assurance problems. It follows that 'for assurance reasons, equality is, necessarily, a social project' (2001, p. 176) - but it does not follow that it need be coercive. $^{7}$

An alternative reason why an egalitarian ethos might be insufficient for justice is that coercion might be required to create an egalitarian ethos. Just as forcing children to eat with good manners fosters an ethos of etiquette when they are adults, so too citizens might develop an ethos of giving voluntarily only if they are first forced to do so by the state. In other words, Cohen might be wrong when he claims that ethoses are 'beyond the immediate control of legislation'. (Cohen 1991, pp. 315-6) Certainly it is at least plausible that ethoses are affected by state action. ${ }^{8}$ But note that, if the egalitarian ethos is to retain any significance, direct coercion cannot be needed permanently. It may be that individuals newly liable to contribute to redistribution must be coerced for a time in order to develop an ethos. This period would like the general justified coercion of children: necessary in order for them to become autonomous moral citizens. But if citizens need ongoing coercion in order to maintain their ethos it is not clear in what sense they really have one. The arguments of this paper still apply, then, to those who have become autonomous citizens.

\section{Is coercion justified?}

The final stage in our argument is to show that, if the egalitarian ethos is both necessary and sufficient for justice, then coercion is unjustified and the libertarian challenge of charity 
stands. Indeed, the importance of liberty to liberal conceptions of justice means that if principles of justice do not need to be enforced coercively it is unjust to use coercion. Not only does coercion imply that the society is not in fact well-ordered and thus not just, it also involves the use of force where none is needed. And using force where none is needed seems to violate the equal basic liberty principle (and other similar statements of the liberal value of freedom), since it would be possible to increase everyone's liberty while threatening noone's. Cohen must, therefore, succumb to the libertarian challenge and accept that the principles of justice (or, at least, the principles of distributive justice) need not and should not be coercively enforced.

Coercion is only needed and justified, therefore, when a society lacks an egalitarian ethos. According to Cohen's arguments, this will occur only when people do not support the principles of justice. But saying that coercion is justified because people disagree about what justice requires is already to concede a fair amount to the libertarian challenge, since it is to concede that coercive redistribution is required because people do not agree that it is justified. Cohen is thus left with the unpalatable conclusion that coercion is required only if citizens do not feel that it is justified and, since the ethos is necessary for justice, despite the fact that it will not bring about justice. Cohen's own arguments thus suggest the appeal of the libertarian call for leaving redistribution to the voluntary acts of individuals.

At one point, however, Cohen does state that his aim is not to deny the need for a coercive state, but rather to deny that there is a justification for rejecting the egalitarian ethos. Thus he writes:

\footnotetext{
That I know or fear that I would not give off my own bat is indeed a reason for me to prefer redistribution through the state, but it is not what we are looking for, which is a justification for not giving if the state does not force me to. It can't be a justification for not giving when the state does not force me to that I would not give unless the state forces me to. (Cohen 2001, p. 170)
} 
Cohen thus suggests that an individual might well prefer to be coerced into giving. But if he concedes this point, Cohen must concede several others. First, he must reject the priority of the equal basic liberty principle. For, if it is possible for individuals to comply with the demands of justice without coercion then there is no good reason to limit liberty by introducing coercion simply for the sake of convenience. Second, if Cohen concedes that the egalitarian ethos can be insufficient to bring about egalitarian outcomes, such that state coercion is justified, he is vulnerable to Scheffler's critique of his position discussed earlier. If the state can bring about justice in cases where the ethos has failed why, pace Scheffler, can it not do so in all cases? Why, in other words, would the ethos be needed at all? It seems that, in order to survive Scheffler's critique, Cohen must retract the implication of the passage quoted above in favour of the intuitively appealing claim that a necessary ethos is also sufficient. After all, if the egalitarian ethos means that people willingly sacrifice their own self-interest in the name of equality above and beyond what the state can practically or legitimately achieve, it makes sense to think that they will be even more willing to do so in cases clear enough to ground coercion.

Cohen's approach thus cannot rebut the libertarian challenge of charity. If an egalitarian ethos is required for distributive equality then state coercion is unnecessary and therefore unjustified. To put it another way, if people not only agree with the principles of justice but are also motivated to comply with them there is no role for redistributive taxation.

\section{Conclusion}

It is now possible to pull together the threads of the argument, and emphasise how the first part of the chapter on comprehensive liberalism, political liberalism, and deliberative democracy connects with the second part on Cohen. Earlier in the chapter, we argued that 
certain forms of liberalism can offer more (and better) responses to the libertarian challenge of charity than others. We suggested that the most coherent and powerful response can be provided by comprehensive liberalism, which can state that coercive redistribution is simply a requirement of justice irrespective of whether people actually believe it to be. The coercive redistribution of holdings from the most advantaged to the least advantaged is simply required by liberal commitments to individual autonomy and equality, and hence, it is just. We suggested that political liberals are less able to rebut the libertarian critique as a consequence of their unwillingness to appeal to controversial principles. The political liberal approach of deriving regulative principles of justice from agreements made between individual citizens rather than the stated good of principles like individual autonomy or equality undermines the liberal justification for coercion, and presents political liberals with a choice. They can either structure the agreement process such that it can only produce outcomes which are consistent with comprehensive liberal principles, in which case their rejection of comprehensive liberalism is rendered hollow, or they can commit themselves to a deliberative process which is not weighted towards liberal outcomes, and which genuinely seeks to model the preferences of the people involved. If the latter option is taken, then political liberals must be willing not only to bear the costs of this more democratised form of liberalism (in the sense that outcomes may violate wider liberal principles) but to make use of the weakest response to libertarianism of all: the response of motivation.

Consequently, liberals who are able to make the response of disagreement have the strongest normative justification for coercion, since they can deny that disagreement (which is what makes coercion necessary) undermines the legitimacy of justice. Justice is justice, regardless of the views of the citizenry. The response of unreasonableness is weaker since it admits that assent to the principles of justice is generally important and thus that the requirement of coercion is suboptimal. Finally, the response of motivation (offered on its 
own) is the weakest of all, since coercion is justified by expediency alone. However, if Cohen is right about motivation and the egalitarian ethos, then the response of motivation is not really a response at all. Cohen's arguments are important for two reasons. The first is that they undermine the response of motivation, and thus leave those political liberals who do not wish to appeal to comprehensive liberal accounts of the good without an adequate reply to the libertarian challenge of charity. The second is that they imply that distributive justice cannot legitimately be coercively enforced. They thus concede the libertarian challenge.

What Cohen's argument suggests is that any form of liberalism which relies on the response of motivation to rebut the libertarian critique of coercive redistribution will not, in fact, be able to rebut this critique. This is a problem because the dominant trend in contemporary liberal thought is to reject the comprehensive approach and adopt a more deliberative approach, more capable of establishing a conception of justice in societies characterised by cultural, ethnic, and religious diversity. As liberals have increasingly turned their gaze away from longstanding debates between libertarians and liberal egalitarians about the rightful distribution of resources and goods and towards issues arising out of multiculturalism, they have argued in ways which have left their liberal egalitarian premises vulnerable to much older, much more established critiques advanced by libertarians. If our argument in this chapter holds then, in seeking to determine the appropriate conduct of social and political institutions through agreements made between citizens rather than prior values like autonomy and equality, political liberals and deliberative democrats are less able to defend egalitarian claims for redistribution than they otherwise think. Indeed, if Cohen is right, then it would seem that they are not able to defend egalitarian claims at all, without first rejecting their wider aim of establishing a free-standing conception of political justice. 


\section{Notes on contributors}

Clare Chambers is University Lecturer in Philosophy and Fellow of Jesus College, University of Cambridge. Her recent publications include Sex, Culture, and Justice: The Limits of Choice (Penn State University Press, 2008); "Inclusivity and the constitution of the family" in Canadian Journal of Law and Jurisprudence (forthcoming 2009); and "Gender" in Catriona McKinnon (ed.) Issues in Political Theory (Oxford University Press, 2008). She is currently writing a book on marriage and the state.

Phil Parvin is Leverhulme Early Career Fellow in the Department of Politics, and a Fellow of Trinity Hall, University of Cambridge. He is author of numerous articles on issues at the intersection of political theory and practice, including 'What's Special About Culture? Identity, Autonomy, and Public Reason', Critical Review of International, Social, and Political Philosophy 11/3 (2008), p. 315 - 333; Friend or Foe? Lobbying in British Democracy (Hansard Society, 2007); and Neglecting Democracy: Participation \& Representation in $21^{\text {st }}$ Century Britain, $2^{\text {nd }}$ Edition (Hansard Society, 2006, with Declan McHugh). His book Karl Popper will be published by Continuum Press in 2009/10.

\section{References}

Barry, B.M., 1995. Justice as impartiality. Oxford: Oxford University Press.

Carter, A., 2006a. The evolution of Rawls's justification of political compliance: part 1 of the problem of political compliance in Rawls's theories of justice. The journal of moral philosophy, 3, 7 - 21 .

Carter, A., 2006b. Political liberalism and political compliance: part 2 of the problem of political compliance in Rawls's theories of justice. The journal of moral philosophy, 3, 135- 157.

Chambers, C., 2008. Sex, culture, and justice. University Park, PA: Penn State University Press.

Chambers, C. and Parvin, P., Forthcoming. What kind of dialogue do we need? Gender, deliberative democracy and comprehensive values. In: Jude Browne, ed., Dialogue, ethics and gender identity.

Cohen, G.A., 1991. Incentives, Inequality, and Community. In: G. Peterson, ed., The Tanner Lectures on Human Values. Salt Lake City, UT: University of Utah Press.

Cohen, G.A., 2001. If you're an egalitarian, how come you're so rich? Cambridge, MA: Harvard University Press.

Galston, W., 2002. Liberal pluralism: the implications of value pluralism for political theory and practice. Cambridge: Cambridge University Press.

Gutmann, A. \& Thompson, D., 2002. Deliberative democracy beyond process. The journal of political philosophy, 10, 153-178.

Kymlicka, W., 1989. Liberalism, community and culture. Oxford: Clarendon Press.

Larmore, C., 1995. Political liberalism. In C. Larmore, The morals of modernity. Cambridge University Press, $121-151$.

MacIntyre, A., 1996. After virtue: a study in moral theory. London: Duckworth.

Nagel, T., 1991. Equality and partiality. Oxford: Oxford University Press.

Nozick, R., 1993. Anarchy, state and utopia. Oxford: Blackwell.

Rawls, J., 1971. A theory of justice. Oxford: Oxford University Press.

Rawls, J., 1993. Political liberalism. New York: Columbia University Press. 
Raz, J., 1986. The morality of freedom. Oxford: Clarendon Press.

Sandel, M., 1982. Liberalism and the limits of justice. Cambridge: Cambridge University Press.

Scheffler, S., 2006. Is the Basic Structure Basic? In: Christine Sypnowich, ed., The egalitarian conscience.

Oxford: Oxford University Press.

Taylor, C., 1992. Sources of the self. Cambridge: Cambridge University Press.

Wall, S., 1998. Liberalism, perfectionism, and restraint. Cambridge: Cambridge University Press.

Walzer, M., 1985. Spheres of justice: a defence of pluralism and equality. Oxford: Blackwell.

Williams, A., 1998. Incentives, inequality, and publicity. Philosophy \& public affairs, 27, 225-47.

Young, I.M., 2000. Inclusion and democracy. Oxford: Clarendon Press.

Notes

${ }^{1}$ Previous versions of this paper were presented at the APSA annual meeting in Chicago, Political Theory Research Seminars at the Universities of Edinburgh and Manchester, and Philosophy Research Seminars at the Universities of Bristol and Glasgow. We are very grateful to the participants for their extremely helpful comments. We should also like to thank Steven Montgomery and Adam Tebble for written comments.

${ }^{2}$ One way that Nozick phrases this challenge is as follows: 'Any persons who favor a particular end-state pattern may choose to transfer some or all of their own holdings so as (at least temporarily) more nearly to realize their desired pattern'. (1993: 232-3.) Nozick makes a mistake, of course, when saying that 'Any persons' may do this, since those who feel that they should have more resources under their preferred distribution cannot act unilaterally without violating the entitlements of others. However, Nozick's claim is true of all those who would be subject to coercive taxation under an egalitarian scheme. Nozick' general discussion of what he calls 'Philanthropy' occurs on pp. 265-8.

${ }^{3}$ Alan Carter has gone further, arguing that political liberalism lacks the resources needed to justify a state that is coercive in any area, not just redistribution. For more on this, see Carter 2006a and 2006b.

${ }^{4}$ For a critique of this view see Chambers and Parvin (Forthcoming).

${ }^{5}$ We have explored this issue in more depth elsewhere. See Chambers and Parvin (Forthcoming). For an interesting discussion of the problem of compliance in Rawls's work, and the inability of political liberalism to provide a unique and coherent response to illiberal diversity, see Carter 2006a and 2006b.

${ }^{6}$ Scheffler has further arguments against Cohen, but it is only his argument about the potential of state coercion to replace an egalitarian ethos that concerns us here.

${ }^{7}$ Note that it is by no means obvious that individuals have grounds to refuse to contribute without coercion even if they lack information about others' ethoses. There is a large literature, which cannot be discussed here, 
arguing against the idea that individuals have duties of justice only when their society is characterised by perfect compliance.

${ }^{8}$ For an extended analysis and defence of the thesis of social construction see Chambers 2008 